\title{
CONVERSION OF CRUDE GLYCEROL TO 1, 3-PROPANEDIOL BY NEWLY ISOLATED Kluyvera cryocrescens
}

\author{
SOH KHEANG LOH* and STASHA ELEANOR ROSLAND ABEL*
}

\begin{abstract}
Biodiesel, an environmental-friendly and renewable fuel, has gained market share and popularity as an alternative to fossil fuel. While expanding its production globally to meet the demand, the production of its principal co-product, crude glycerol which is surplus and under utilised, has affected both the economic and environment. Crude glycerol has limited usage due to the impurities present. It cannot be disposed naturally in the environment and its storage and processing are very costly. Glycerol with its triglyceride backbone serves as a natural metabolite susceptible to microbial degradation into high value-added compounds. In this study, a novel 1,3-PD producing bacterial strain isolated from palm oil mill effluent was used in microbial fermentation of crude glycerol. The strain, identified as Kluyvera cryocrescens NBRC 102467 based on its $16 S$ rRNA sequences, was capable of producing 1,3-PD (5.28 $\left.\mathrm{g} \mathrm{litre}^{-1}\right)$ along with by-products, butanol $\left(0.34 \mathrm{~g} \mathrm{litre}^{-1}\right)$ and acetone $\left(0.31 \mathrm{~g} \mathrm{litre}^{-1}\right)$ after an optimum $48 \mathrm{hr}$ of incubation at $30^{\circ} \mathrm{C}$ in agitated medium enriched with crude glycerol at $150 \mathrm{rpm}$. Interestingly, its productivity peaked at the $6 \mathrm{hr}$ reaching $0.28 \mathrm{glitre}^{-1} \mathrm{hr}^{-1}$ and declined thereafter. In future, this strain has potential to be used in the bioprocess of interest.
\end{abstract}

Keywords: glycerol-catabolising strains, palm oil mill effluent, 1, 3-propanediol, acetone, butanol, bioprocess, Kluyvera cryocrescens.

Date received: 30 June 2015; Sent for revision: 10 July 2016; Received in final form: 17 March 2016; Accepted: 24 March 2016.

\section{INTRODUCTION}

Basically, biodiesel can be produced from vegetable oils, animal fats or recycled greases. It is an environmentally attractive alternative fuel, which holds technical benefits such as inherent lubricity, low toxicity as well as renewability. In general, nearly $10 \mathrm{~kg}$ of glycerol is produced, for every 100 $\mathrm{kg}$ of biodiesel formed (Chatzifragkou et al., 2014). The utilisation of glycerol for the synthesis of value-added chemicals is a topic of great industrial interest because the growth of the biodiesel industry

Malaysian Palm Oil Board

6 Persiaran Institusi, Bandar Baru Bangi, 43000 Kajang,

Selangor, Malaysia.

E-mail: lohsk@mpob.gov.my has thus generated an excess of waste glycerol. This occurrence is unavoidable due to its restricted application owing to the presence of impurities, in contrast to pure glycerol (Nik et al., 2013; Johnson and Taconi, 2007).

To date, the bioconversion of crude glycerol into value-added products in the forms of solvents and organic acids seems to be the most practical and feasible as it is able to circumvent the disadvantages of chemical processes (Da Silva et al., 2015; Gallardo et al., 2014; Nimje et al., 2011; Makri et al., 2010). Among the many promising applications for glycerol, bioconversion into 1,3-propanediol (1,3-PD) has received much attention especially in recent years (Da Silva et al., 2015; Pachapur et al., 2015; Metsoviti et al., 2012; Wilkens et al., 2012; Chatzifragkou et al., 2011). As early as 1881, 1,3-PD was reliably 
identified by August Freund as a product of glycerol fermentation by Clostridium pasterianum. He has further demonstrated the microbial conversion of pure glycerol into 1,3-PD using several bacterial strains taking into consideration that crude glycerol especially at high concentration (due to the presence of impurities) might pose toxicity towards microbial strains.

In particular, 1,3-PD is a chemical used to improve the properties of various adhesives, laminates, cosmetics and solvent. It is also a feedstock for other useful chemicals and can be efficiently used as polyglycol-based lubricant (Chatzifragkou et al., 2011). Besides, 1,3-PD is also a commodity chemical mainly used as a building block in polymerisation, especially in the manufacture of polytrimethylene terephthalate (PTT). Conventionally, 1,3-PD is chemically synthesised via two major routes, reacting 3-hydroxypropionaldehyde with either acrolein or ethylene oxide. Nevertheless, the resulting catalyst-assisted chemical procedure involving high pressure and temperature is very costly and requires extreme safety measures for operation (Yuanman et al., 2015). In recent years, interest towards its conversion via biological process is renewed as it is less risky and requires less energy input because it is fermentation-based. Therefore, microbial conversion of glycerol into 1,3-PD is relatively more favourable as it is environmentalfriendly, more economical and evidently more productive compared to chemical synthesis (Wilkens et al., 2012; Jun et al., 2010; Da Silva et al., 2009). However, considering the possible encumbrance of lowering metabolite production in biochemical synthesis caused by the impurities present in crude glycerol, it is only wise to search for practical and sustainable disposal means in coping with its ever increasing amount from the biodiesel industry.

A number of microorganisms are capable of biologically producing 1,3-PD from glycerol such as Klebsiella pneumoniae (Homann et al., 1990), Clostridium butyricum (Colin et al., 2000; Daria, 2014), Citrobacter freundii (Boenigk et al., 1993), Pelobacter carbinolicus, Rautella planticola, Bacillus welchii (Saxena et al., 2009), engineered strain of Escherichia coli

\section{TABLE 1. THE COMPOSITION* OF CRUDE GLYCEROL FROM SIME DARBY BIODIESEL SDN BHD, SELANGOR, MALAYSIA}

\begin{tabular}{cc}
\hline Component & Concentration $\%(w / v)$ \\
\hline Glycerine & 79.3 \\
Water & 6.69 \\
Soap & 16.2 \\
Methanol & 7.3 \\
Oil & 0.97 \\
\hline
\end{tabular}

Note: * According to the company's description.
(Xueming et al., 2009) and Trichococcus flocculiformis (Antonie et al., 2012). Many new technologies for the efficient use of this raw material are currently being exploited and developed. Many of the promising glycerol-catabolising strains originated from soil and other resources with less focus on utilising a cheap and abundant wastewater. Hence, the aim of this work was to identify and characterise the potential bacterial strain from palm oil mill effluent (POME) that can produce 1,3-PD using crude glycerol derived from biodiesel manufacturing.

\section{MATERIALS AND METHODS}

\section{Materials}

Crude glycerol (Table 1) was obtained from Sime Darby Biodiesel Sdn Bhd (Selangor, Malaysia). All chemicals were purchased from Sigma-Aldrich (USA) and Merck. Meanwhile, the POME samples were collected from the aerobic and anaerobic ponds at MPOB's Palm Oil Mill Technology Centre (POMTEC) in Labu, Negeri Sembilan, Malaysia.

\section{Enrichment and Isolation of Microorganisms}

The enrichment and isolation of bacteria from POME was carried out in Luria Bertani (LB) medium consisting of ( $\left.\mathrm{g}^{\text {litre }}{ }^{-1}\right)$ : glycerol, 20; peptone, 10; $\mathrm{NaCl}$, 9; yeast extract, 5 at $\mathrm{pH}$ 7. Each isolated bacterial strain was inoculated in a $250-\mathrm{ml}$ flask with $100 \mathrm{ml}$ enrichment medium and then incubated for $24 \mathrm{hr}$ at $30^{\circ} \mathrm{C}$ in an incubator shaker at $150 \mathrm{rpm}$. After the incubation period, the above samples were subjected to a serial dilution using sterile distilled water and $0.1 \mathrm{ml}$ of each dilution was then plated out onto a solid mineral salt medium (MSM) and incubated at $30^{\circ} \mathrm{C}$. The plates were incubated overnight and the colony count was recorded. For growth and metabolite analysis, isolated strains on agar plate culture were subsequently transferred to liquid culture containing the same medium composition except for agar.

\section{Shake Flask Fermentation Condition}

Each screened strain was first cultured in a shake flask to identify if 1,3-PD was a metabolic product of the strain. The medium used for the fermentation composed of $\left(\mathrm{g} \mathrm{litre}^{-1}\right)$ : glycerol, 20; $\mathrm{K}_{2} \mathrm{HPO}_{4^{\prime}} 0.69$; $\mathrm{KH}_{2} \mathrm{PO}_{4^{\prime}} 0.25 ;\left(\mathrm{NH}_{4}\right)_{2} \mathrm{SO}_{4^{\prime}} 6 ; \mathrm{MgSO}_{4} \cdot 7 \mathrm{H}_{2} \mathrm{O}, 0.2$; yeast extract, 1.5 and $1 \mathrm{ml}$ of trace element solution. The composition of the trace element solution was $(\mathrm{mg}$ litre-1): $\mathrm{MnSO}_{4} \cdot 4 \mathrm{H}_{2} \mathrm{O}, 100 ; \mathrm{ZnCl}_{2}, 70 ; \mathrm{Na}_{2} \mathrm{MoO}_{4} \cdot 2 \mathrm{H}_{2} \mathrm{O}$, $35 ; \mathrm{H}_{3} \mathrm{BO}_{3^{\prime}} 60 ; \mathrm{CoCl}_{2} .6 \mathrm{H}_{2} \mathrm{O}, 200 ; \mathrm{CuSO}_{4} .5 \mathrm{H}_{2} \mathrm{O}, 29.28$; $\mathrm{NiCl}_{2} \cdot 6 \mathrm{H}_{2} \mathrm{O}, 25$ and $37 \% \mathrm{HCl}, 0.9 \mathrm{ml}$. The culture was incubated at $30^{\circ} \mathrm{C}$ for $48 \mathrm{hr}$ in an incubator shaker at $150 \mathrm{rpm}$. A 10-ml aliquot sample was withdrawn 
at fixed time interval $(6 \mathrm{hr}, 12 \mathrm{hr}, 24 \mathrm{hr}, 48 \mathrm{hr}$ and $60 \mathrm{hr}$ ) and analysed for 1,3-PD production by high performance liquid chromatography (HPLC).

\section{Analyses}

The concentrations of 1,3-PD and other byproducts were detected and quantified using HPLC (Waters 2707 Autosampler). The culture was centrifuged at $4000 \mathrm{rpm}$ for $10 \mathrm{~min}$ to remove bacterial cells and the supernatant was then filtered through a $0.45-\mu \mathrm{m}$ membrane filter (Nylon) prior to HPLC analysis. Aqueous sulphuric acid $(0.5 \mathrm{mM})$ as a mobile phase was pumped at the rate of $1.0 \mathrm{ml}$ $\min ^{-1}$. Samples were injected and metabolites were analyzed at $60^{\circ} \mathrm{C}$.

To determine dry cell weight, the bacterial cells were centrifuged two times after washing and re-suspending the cells in sterile distilled water. Then, the cells of the isolated bacteria were made into pellet and dried to constant weight in oven at $80^{\circ} \mathrm{C}$. The dry cell weight was calculated using the formula given by Sawada et al. (1977).

Identification and taxonomic classification of the isolated strains were further confirmed via $16 S$ rRNA gene sequencing by First Base Pte Ltd, Selangor, Malaysia. The alignment of the $16 \mathrm{~S}$ rRNA gene sequences was obtained via BLAST searching from the National Centre for Biotechnology Information (NCBI).The cellular morphology of the isolated bacteria was examined using a scanning electron microscope (SEM). For primary fixation process, the sample was cut into $1 \mathrm{~cm}^{3}$ and fixed in a fixative medium (4\% glutaraldehyde) for 12 to 24 $\mathrm{hr}$ at $4^{\circ} \mathrm{C}$. Then, it was washed three times, each for 10 min using $0.1 \mathrm{M}$ sodium cacodylate buffer (SCB). The sample underwent post fixation in 1\% osmium tetroxide for $2 \mathrm{hr}$ at $4^{\circ} \mathrm{C}$, before being washed again with $0.1 \mathrm{M} \mathrm{SCB}$ as above. The fixed cells were dehydrated with acetone $(35 \%, 50 \%, 75 \%, 95 \%$ and $100 \%$ concentration) and dried using Critical Point Dryer (Leica CPD). The cells were coated with gold for 2 min. Finally, the coated sample was observed under SEM (Hitachi SU1510) and the SEM image captured at 5000X and 10 000X magnification.

\section{RESULTS AND DISCUSSION}

\section{Screening and Identification of 1,3-PD-producing Microorganisms}

Many bacteria colonies were found growing on the MSM of the isolation plates. Five different types of colonies were isolated and further purified on LB agar plates. The physiological properties of the five bacteria isolates are summarised in Table 2. One such purified strain, coded NPP, showed potential in utilising glycerol as carbon source. Gram staining showed that this purified strain was a gram-negative rod-shaped bacterium. This finding corresponded well with that of SEM micrograph (Figure 1) showing similar morphology of NPP. The metabolite analysis by HPLC revealed that NPP was able to produce 1,3$\mathrm{PD}$ as the major metabolite. This strain also, at the same time, secreted some other metabolic products such as butanol and acetone (Figure 2). According to Biebl et al. (1999), microorganisms in nature could use glycerol as substrate and convert it into 1,3-PD.

This new 1,3-PD-producing strain was taxonomically identified to be Kluyvera cryocrescens NBR 102467 (with 99\% similarity via NCBI BLAST). According to Farmer et al. (1981), strains of Kluyvera share the properties of most members of the family Enterobacteriaceae: catalase positive, oxidase negative

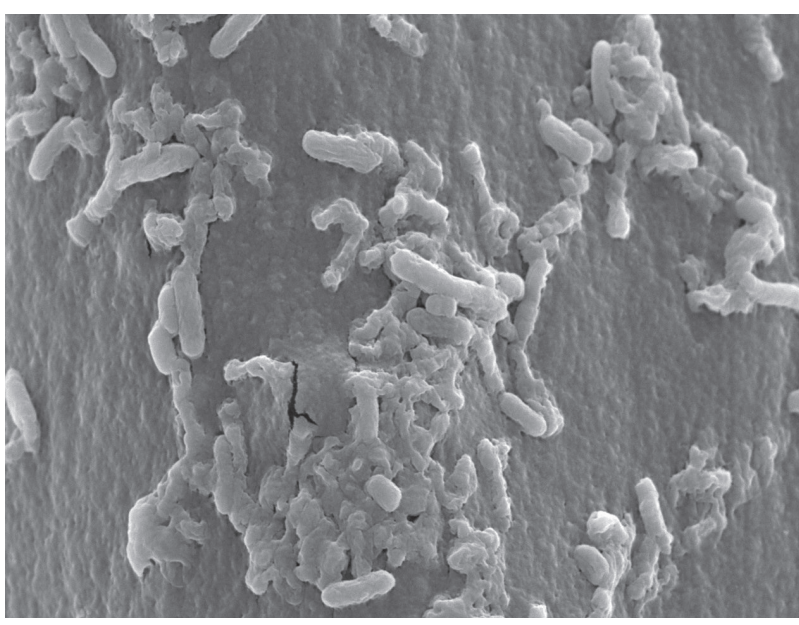

Figure 1. Scanning electron micrograph of Kluyvera cryocrescens under $10000 X$ magnification.

TABLE 2. MORPHOLOGICAL AND CHARACTERISTICS OF THE FIVE BACTERIA ISOLATES

\begin{tabular}{lccccc}
\hline Characteristics & \multicolumn{5}{c}{ Strains } \\
\cline { 2 - 5 } & NPP & E2-1P & EP-Ca & E1-2P & N1-2P \\
\cline { 2 - 6 } Cell shape & Rod & Rod & Rod & Rod & Rod \\
Elevation & Flat & Flat & Raised & Flat & Convex \\
Margin & Entire & Entire & Entire & Undulate & Entire \\
Pigmentation & Cream & Cream & White & White & Cream \\
Gram stain & - & - & - & - & + \\
Colony shape & Circular & Punctiform & Irregular & Circular & Irregular \\
\hline
\end{tabular}




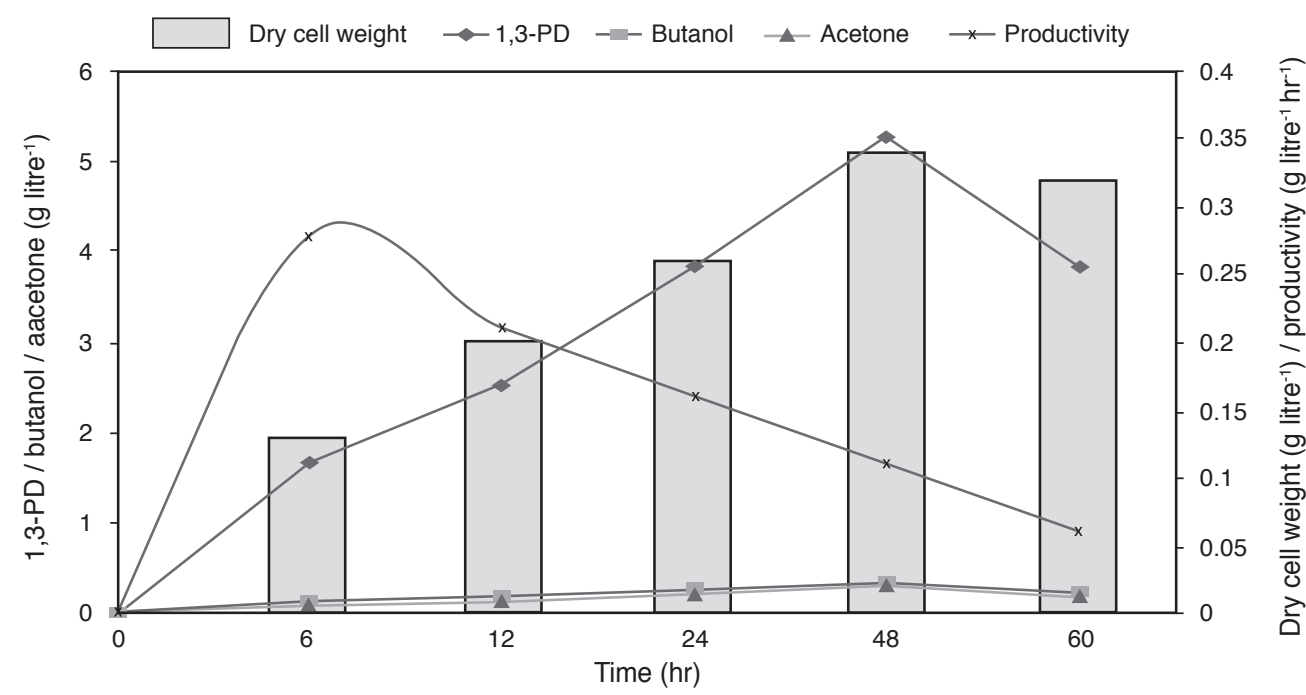

Figure 2. Fermentation of Kluyvera cryocrescens in crude glycerol at $30^{\circ} \mathrm{C}, 150 \mathrm{rpm}$ for the production of 1,3-PD and other by-products.

and they grow on MacConkey agar. Besides, the cell dry weight shown in Figure 2 indicated that NPP's cell growth reached $0.13 \mathrm{~g} \mathrm{litre}^{-1}$ at the initial $6 \mathrm{hr}$ fermentation and doubled up after $18 \mathrm{hr}$ on MSM medium. The maximum growth as reflected by the dry cell weight of $0.34 \mathrm{~g}$ litre $^{-1}$ was achieved at the 48 hr of incubation at $30^{\circ} \mathrm{C}$.

\section{Production of 1,3-PD by K. cryocrescens}

The shake flask fermentation of $K$. cryocrescens with crude glycerol was performed to assess its capability in 1,3-PD production (Figure 2). Despite the impurities present in crude glycerol (Table 1), the strain NPP was capable of producing 1,3-PD, reaching a maximum concentration of $5.28 \mathrm{~g} \mathrm{litre}^{-1}$ at $48 \mathrm{hr}$ and productivity of $0.11 \mathrm{~g}^{\text {litre }} \mathrm{hr}^{-1}$ (Figure 2). Besides 1,3-PD, acetone and butanol were also generated in the fermentation medium. Butanol and acetone were produced at very much lower concentrations, i.e. $0.34 \mathrm{~g} \mathrm{litre}^{-1}$ and $0.31 \mathrm{~g} \mathrm{litre}^{-1}$ (max), respectively. However, the production of 1,3-PD and by-products (butanol and acetone) decreased at the $60 \mathrm{hr}$. This declined production might be due to the depletion of nutrients, hence commencement of an initial dead phase as was evidenced by the declined dry cell weight.

Accordingly, the presence of salt and methanol as the impurities does not influence the growth and metabolism of the bacteria in glycerol (Keerthi et al., 2012), whereas the higher concentration of unsaturated fatty acid such as linoleic acid in the oil could possibly inhibit the microbial degradation of glycerol by bacteria. The presence of double bond of the oil molecule makes it susceptible to free radical attack in the presence of $\mathrm{O}_{2}$, influencing the oxidative stability of an oil and resulting in an unfavourable environment for microbial rejuvenation. On the contrary, the presence of saturated fatty acid in lower concentration such as stearic and oleic acid is seemingly less harmful to substrate utilisation. Hence, the removal of fatty acids or oil from crude glycerol is crucial towards the higher and optimum production of 1,3-PD. In future, it is necessary to carry out further experiments with $\mathrm{pH}$ control and to optimise some of the process parameters in attempts to increase the yield and productivity of 1,3-PD and or the co-products. The fed-batch production of 1,3-PD using a lab-scale fermentor based on the optimised fermentation conditions will follow suit.

\section{CONCLUSION}

K. cryocrescens was identified as a potential bacteria strain that was able to assimilate crude glycerol to produce 1,3-PD as the main product and butanol and acetone as by-products. This strain had the capability to consume crude glycerol even in its impure (contaminated) form. The 1,3-PD production reached $5.28 \mathrm{~g} \mathrm{litre}^{-1}$ after $48 \mathrm{hr}$ of incubation. To date, there is no study yet on production of 1,3-PD by $K$. cryocrescens using crude form of glycerol, thus it has the potential of contributing to new applications in glycerol metabolism.

\section{ACKNOWLEDGEMENT}

The authors thank the Director-General of MPOB for permission to publish this article.

\section{REFERENCES}

ANTONIE, H V G; ROZELIN, A; MADALENA, M A and ALFONS, J M S (2012). 1,3-propanediol production from glycerol by a newly isolated Trichococcus strain. Microbial Biotechnology Vol. 5(4): 573-578. 
BIEBL, H; ZENG, A P; MENZEL, $\mathrm{K}$ and DECKWER, W D (1999). Fermentation of glycerol to 1,3-propanediol and 2,3-butanediol by Klebsiella pneumoniae. Applied Microbiology and Biotechnology, 50: 24-29.

BOENIGK, R; BOWIEN, S and GOTTSCHALK, G (1993). Fermentation of glycerol to 1,3-propanediol in continuous cultures of Citrobacter freundii. Applied Microbial and Biotechnology, 38: 453-457.

CHATZIFRAGKOU, A; PAPANIKOLAOU, $S$; DIETZ, D; DOULGERAKI, A I; NYCHAS, G J E and ZENG, A P (2011). Production of 1,3-propanediol by Clostridium butyricum growing on biodiesel-derived crude glycerol through a non-sterilized fermentation process. Applied Microbiology and Biotechnology, 91: $101-112$

CHATZIFRAGKOU, A; PAPANIKOLAOU, $S$; KOPSAHELIS, $\mathrm{N}$; KACHRIMANIDOU, $\mathrm{V}$; DORADO, M P and KOUTINAS, A A (2014). Biorefinery development through utilization of biodiesel industry by-products as sole fermentation feedstock for 1,3-propanediol production. Bioresource Technology, 159: 167-175.

COLIN, T; BORIES, A and MOULIN, G (2000). Inhibition of Clostridium butyricum by 1,3-propanediol and diols during glycerol fermentation. Applied Microbial and Biotechnology, 54: 201-205.

DARIA, S P (2014). 1,3-Propanediol production from crude glycerol by Clostridium butyricum DSP1 in repeated batch. Electronic J. Biotechnology, 17: 322328.

DA SILVA, G P; MACK, M and CONTIERO, J (2009). Glycerol: a promising and abundant carbon source for industrial microbiology. Biotechnology Advance, $27: 30-39$

DA SILVA, G P; BOLNER DE LIMAB, C J and CONTIERO, J (2015). Production and productivity of 1,3-propanediol from glycerol by Klebsiella pneumoniae GLC29. Catalysis Today Vol. 257(2): 259 266.

FARMER, J J 3 ${ }^{\text {rd }}$; FANNING, G R; HUNTLEYCARTER, G P; HOLMES, B; HICKMAN, F W; RICHARD, C and BRENNER, D J (1981). Kluyvera, a new (redefined) genus in the family Enterobacteriaceae: identification of Kluyvera ascorbata sp. nov. and Kluyvera cryocrescens sp. nov. in clinical specimens. J. Clinical Microbiology Vol. 13(5): 919-933.

GALLARDO, R; ALVES, $\mathrm{M}$ and RODRIGUES L R (2014). Modulation of crude glycerol fermentation by Clostridium pasteurianum DSM 525 towards the production of butanol. Biomass and Bioenergy, 71: 134-143.

HOMANN, T; TAG, C L; BIEBL, H; DECKWER, W D and SCHINK, B (1990). Fermentation of glycerol to 1,3-propanediol by Klebsiella and Citrobacter strains. Applied Microbiology and Biotechnology, 33: 121-126.

JOHNSON, D T and TACONI, K A (2007). The glycerin glut: options for the value added conversion of crude glycerol resulting from biodiesel production. Environmental Progress, 26: 338-348.

JUN, S A; MOON, C; KANG, C H; KONG, S W; SANG, B I and UM, Y (2010). Microbial fed-batch production of 1,3-propanediol using raw glycerol with suspended and immobilised Klebsiella pneumoniae. Applied Biochemistry and Biotechnology, 161: 491-501.

KEERTHI, P V; JUDY, J B; YOGI, K.; KATHERINE, A T; GEOFFREY, D B and CARMEN, S (2012). Impact of impurities in biodiesel-derived crude glycerol on the fermentation by Clostridium pasteurianum ATCC 6013. Applied Microbiology and Biotechnology, 93: 1325-1335.

MAKRI, A; FAKAS, S and AGGELIS, G (2010). Metabolic activities of biotechnological interest in Yarrowia lipolytica grown on glycerol in repeated batch cultures. Bioresource Technology, 101: 2351-2358.

METSOVITI, M; PARASKEVAIDI, K; KOUTINAS, A; ZENG, A P and PAPANIKOLAOU S (2012). Production of 1,3-propanediol, 2,3-butanediol and ethanol by a newly isolated Klebsiella oxytoca strain growing on biodiesel-derived glycerol based media. Process Biochemistry, 47: 1872-1882.

NIK, S M N M D; ZAINAB, I; YEONG, S K and HAZIMAH, A H (2013). Preparation of polyglycerol from palm-biodiesel crude glycerin. J. Oil Palm Res. Vol. 25(3): 289-297.

NIMJE, V R; CHEN, C Y; CHEN, C C; CHEN, H R; TSENG, M J; JEAN, J S and CHANG, Y F (2011). Glycerol degradation in single-chamber microbial fuel cells. Bioresource Technology, 102: 2629-2634.

PACHAPUR, V L; SARMA, S J; BRAR, S K; BIHAN, Y L; BUELNA, G and SOCCOL, C R (2015). Evidence of metabolic shift on hydrogen, ethanol and 1,3-propanediol production from crude glycerol by nitrogen sparging under micro-aerobic conditions using co-culture of Enterobacter aerogenes and Clostridium butyricum. International J. Hydrogen Energy Vol. 40(28): 8669-8676. 
SAWADA, H; PARR, R C and ROGER, P L (1977). Photosynthetic bacteria in waste water treatment. J. Fermentation Technology, 55: 326-336.

SAXENA, RK;PINKI,A;SAURABH,SandJASMINE, I (2009). Microbial production of 1,3-propanediol: Recent developments and emerging opportunities. Biotechnology Advances, 27: 895-913.

WILKENS, E; RINGEL, A K; HORTIG, D; WILKE, T and VORLOP, K D (2012). High-level production of 1,3-propanediol from crude glycerol by Clostridium butyricum AKR102a. Applied Microbiology and Biotechnology Vol. 93(3): 1057-1063.
XUEMING, T; YONGSONG, T; HONG, Z; KAI, $\mathrm{Z}$ and WEI, S (2009). Microbial conversion of glycerol to 1,3-propanediol by an engineered strain of Escherichia coli. Applied and Environmental Microbiology Vol. 75(6): 1628-1634.

YUANMAN, Z; JI'AN, L; XUEBING, Z and DEHUA, L (2015). A novel strategy for 1,3-propanediol recovery from fermentation broth and control of product colority using scraped thin-film evaporation for desalination. RSC Advances, 5: 48269-48274.

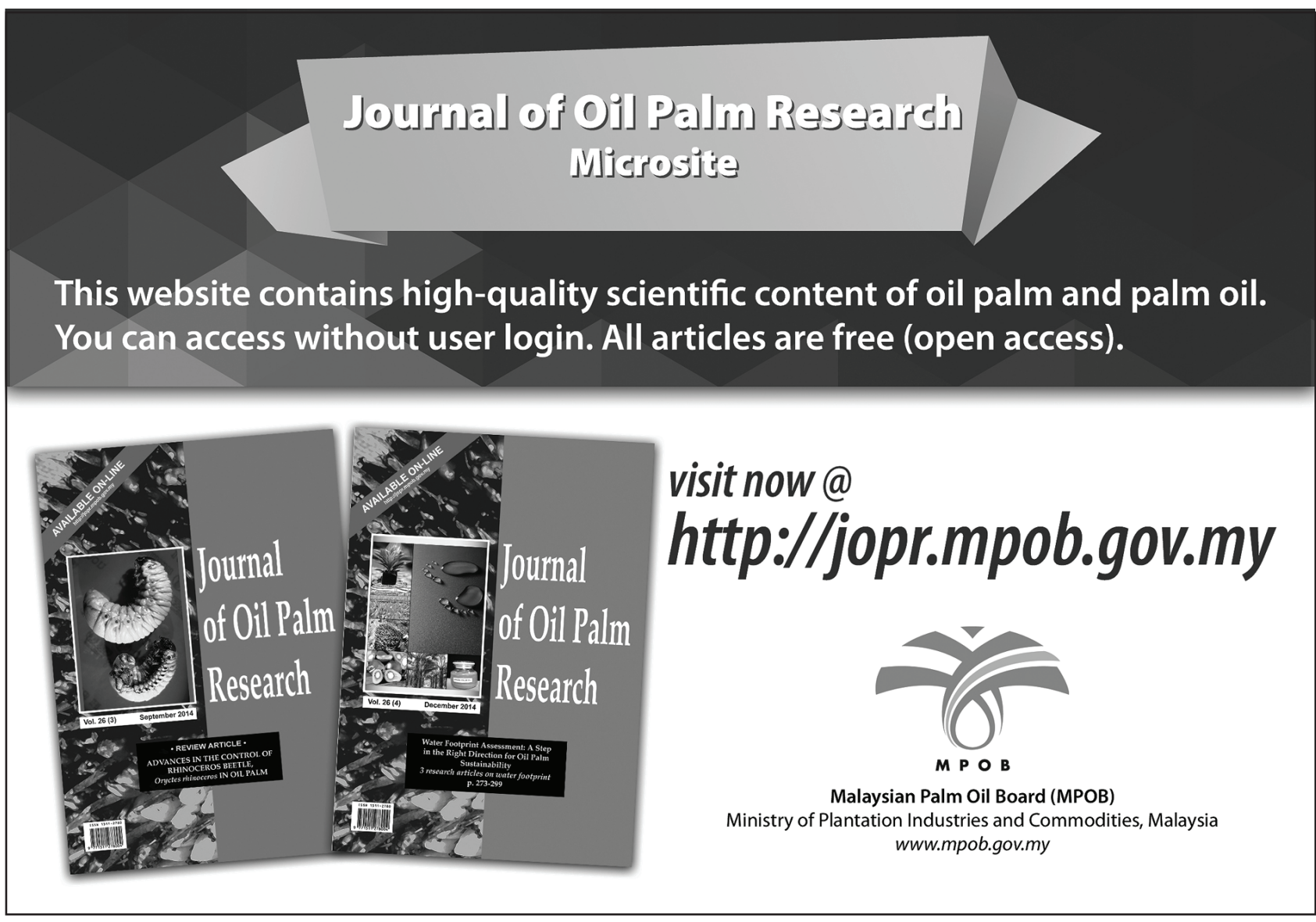

